PACS: 52.25.Os, 52.20.Dq, 52.55.Fa

\title{
SPECTRA ANALYSIS OF RUNAWAY ELECTRON SYNCHROTRON RADIATION FOR THE RECENT EAST RUNAWAY EXPERIMENT
}

\author{
I.M. Pankratov ${ }^{1,2}$, V.Y. Bochko ${ }^{2}$ \\ ${ }^{1}$ Institute of Plasma Physics, NSC "Kharkiv Institute of Physics and Technology" \\ Academicheskaya Str.1, 61108 Kharkiv, Ukraine \\ ${ }^{2}$ Department of Physics and Technology, V.N. Karazin Kharkiv National University \\ Svobody Sq.4, 61022 Kharkiv, Ukraine \\ E-mail:pankratov@kipt.kharkov.ua \\ Received June 26, 2017
}

\begin{abstract}
The energy of disruption generated runaway electrons can reach as high as tens of megaelectronvolt and they can cause a serious damage of plasma-facing-component surfaces in large tokamaks like International Thermonuclear Experimental Reactor (ITER). The synchrotron radiation diagnostic allows a direct observation of such runaway electrons and an analysis of their parameters and promotes the safety operation of present day large tokamaks and future ITER. Only this diagnostic will be applied in ITER. In the paper detail analysis of the synchrotron radiation spectra of runaway electrons for the recent Experimental Advanced Superconducting Tokamak (EAST, Institute of Plasma Physics of Chinese Academy of Sciences) experiment parameters has been presented. The calculations are carried out on the base of precise expression for synchrotron radiation spectral density. They make more precise spectra analysis of the previous paper by Zhou R.J., Pankratov I.M., Hu L.Q., et al. (Physics of Plasmas, 2014, Vol. 21, No. 6, 063302). Obtained results are important for correct interpretation of runaway EAST experiments and runaway experiments in other tokamaks.

KEYWORDS: synchrotron radiation, diagnostic runaway electrons, tokamak safety operation, EAST tokamak
\end{abstract}

\section{АНАЛИЗ СПЕКТРОВ СИНХРОТРОННОГО ИЗЛУЧЕНИЯ УБЕГАЮЩИХ ЭЛЕКТРОНОВ ДЛЯ НЕДАВНЕГО ЭКСПЕРИМЕНТА НА ТОКАМАКЕ ЕАST \\ И.М. Панкратов ${ }^{1,2}$, В.Ю. Бочко ${ }^{2}$ \\ ${ }^{1}$ Институт физики плазмы, ННЦ “Харьковский физико- технический институт” ул. Академическая 1, 61108 Харьков, Украина \\ ${ }^{2}$ Физико- технический факультет, Харьковский национальный университет имени В.Н. Каразина пл. Свободы 4, 61022 Харьков, Украина}

Энергия убегающих электронов, образующихся при срывах разряда, может достигать десятков мегаэлектронвольт, что приводит к серьезным повреждениям элементов поверхности первой стенки в больших токамаках, это - потенциальная угроза для Международного термоядерного экспериментального реактора (ИТЭР). Диагностика, основанная на синхротронном излучении убегающих электронов, позволяет как непосредственное их наблюдение, так и анализ параметров этих электронов, что способствует безопасной работе существующих больших токамаков и будущего токамакареактора ИТЭР. Именно эта диагностика будет использована в ИТЭРе. Предоставлен детальный анализ спектров синхротронного излучения убегающих электронов для параметров недавнего эксперимента на токамаке EAST (Институт физики плазмы Академии наук Китая). Расчеты проведены на основе точного выражения для спектральной плотности синхротронного излучения. Они уточняют анализ спектров статьи Zhou R.J., Pankratov I.M., Hu L.Q., et al. (Physics of Plasmas, 2014, Vol. 21, No. 6, 063302). Полученные результаты важны для правильной интерпретации эксперимента на EAST и экспериментов с убегающими электронами на других токамаках.

КЛЮЧЕВЫЕ СЛОВА: синхротронное излучение, диагностика убегающих электронов, безопасность работы токамака, токамак EAST

\section{АНАЛІЗ СПЕКТРІВ СИНХРОТРОННОГО ВИПРОМІНЮВАННЯ ЕЛЕКТРОНІВ - ВТІКАЧІВ ДЛЯ НЕЩОДАВНЬОГО ЕКСПЕРИМЕТУ НА ТОКАМАЦ ЕАSТ I.М. Панкратов ${ }^{1,2}$, В. Ю. Бочко \\ ${ }^{1}$ Інститут фізики плазми, ННЦ "Харківський фізико-технічний інститут" вул. Академічна 1, 61108 Харків, Украӥна \\ ${ }^{2}$ Фізико- технічний факультет, Харківський національний університет імені В.Н. Каразіна м. Свободи 4, 61022 Харків, Украӥна}

Енергія електронів-втікачів, які утворюються під час зривів розряду, може досягати десятків мегаелектронвольт, що призводить до серйозних пошкоджень елементів поверхні першої стінки у великих токамаках, це є потенційною загрозою для Міжнародного термоядерного експериментального реактора (ITEP). Діагностика, що базується на синхротронному випромінюванні електронів - втікачів, дозволяє як безпосереднє їх спостереження, так і аналіз параметрів цих електронів, що сприяє безпечній роботі сучасних токамаків та майбутнього токамаку-реактора ITЕР. Саме ця діагностика буде використана в ITEPі. Представлено детальний аналіз спектрів синхротронного випромінювання електронів-втікачів для параметрів нещодавнього експерименту на токамаці EAST (Інститут фізики плазми Академії наук Китаю). Розрахунки проведені на основі точного виразу для спектральної густини потужності синхротронного випромінювання. Вони уточнюють аналіз спектрів статті Zhou R.J., Pankratov I.M., Hu L.Q., et al. (Physics of Plasmas, 2014, Vol. 21, No. 6, 063302). Отримані результати важливі для правильної інтерпретації експерименту на EAST та експериментів 3 електронамивтікачами на інших токамаках.

КЛЮЧОВІ СЛОВА: синхротронне випромінювання, діагностика електронів - втікачів, безпека роботи токамака, токамак EAST 
Runaway electrons can be a potential threat to the safe operation of large tokamaks, especially ITER. The strong electric fields induced during the tokamak disruption can generate a lot of runaways. The energy of these electrons can reach as high as tens of $\mathrm{MeV}$ and they can cause a serious damage of plasma-facing-component (PFC) surfaces in large tokamaks like ITER [1]. Therefore an effective monitoring of the runaway electrons is an important task.

The synchrotron radiation is a powerful tool for direct observation and investigation of runaway electrons in large tokamaks [2]. For the first time, this diagnostic was used in the TEXTOR tokamak [3]. The established methods of runaway electron monitoring (HXR, photoneutron emission) will be difficult to apply in large machines like ITER because of the high gamma and neutron background and the very thick wall (vessel shielding). Only the diagnostic based on the runaway electron synchrotron radiation measurements will be possible in ITER [4]. The theoretical bases of the analysis of synchrotron radiation spectra of runaway electrons in the curved magnetic field with the finite value of the transverse velocity were considered in [5].

The experiments on investigations of runaway electrons are carrying out in JET (Joint European Torus), JT-60U (Japan), DIII-D (USA), Tore Supra (France), KSTAR (Republic of Korea), etc. (see for example [6-9]). Recently the investigation of runaway electron generation was started in the EAST tokamak (China) [10-11] and the synchrotron radiation diagnostic detecting the runaway electrons is used there. The aim of these experiments is to find tokamak operation scenarios that will reduce runaway current as much as possible (or fully suppress) to avoid damage of PFC.

This paper is a continuation of paper [12], where spectrum analysis was done only for expected runaway electron parameters in EAST. They are differing from parameters obtained in recent runaway EAST experiment [10]. The aim of this work is to provide more detail analysis of synchrotron radiation spectra for this recent runaway EAST experiment (shot \#28957).

\section{MONITORING OF RUNAWAY ELECTRONS}

In Ref. [5], the theoretical analysis of the synchrotron radiation spectra of runaway electrons was carried out. The features of the relativistic electron motion in a tokamak (the motion along the tokamak helical magnetic field, the cyclotron gyration motion around the guiding center with a frequency $\omega_{B}=e B / m c \Gamma$ and the vertical centrifugal drift of guiding center motion with velocity $v_{d r}=v_{\|}^{2} / R \omega_{B}$ ) were taken into account. The local nature of electron orbits was involved: only a small part of the electron trajectory in a tokamak is effective to produce the radiation observed in the detector. Recall that highly relativistic particles emit radiation in the direction of their velocity vector. Here $B$ is the local value of confinement magnetic field, $\Gamma \gg>1$ is the relativistic factor, $R$ is the major radius of runaway electron position, $v_{\|}, v_{\perp}$ are the longitudinal and transversal components of velocity with respect to the confinement magnetic field, $v_{\|} \gg v_{\perp}, e$ and $m$ are the charge and rest mass of electron, $c$ is the light velocity. In case of the EAST tokamak, the confinement magnetic field was taken in the form

$$
\mathbf{B}(r, \theta)=\left[-B_{0} \mathbf{e}_{\varsigma}+B_{\theta}(r) \mathbf{e}_{\theta}\right] / R,
$$

where $B_{0} / \mathrm{R}$ and $B_{\theta}(r) / \mathrm{R}$ are the toroidal and poloidal magnetic field components, respectively, $R=1-\left(r / R_{0}\right) \cos \theta, r$ and $R_{0}$ are the magnetic surface minor and major radii, respectively, $\theta$ is the poloidal angle.

In Ref. [5] the expression for instantaneous spectral density of the emitted power was derived ( $\lambda$ is the wavelength):

$$
\begin{aligned}
P_{\text {full }}(\lambda)= & i \frac{2 \pi c e^{2}}{\lambda^{3} \Gamma^{2}}\left\{\int_{C} \frac{d u}{u}\left(1-2 u^{2}\right) I_{0}\left(a u^{3}\right) \exp \left[-\frac{3}{2} \xi\left(u-\frac{u^{3}}{3}\right)\right]-\right. \\
& \left.-\frac{4 \eta}{1+\eta^{2}} \int_{C} d u \cdot u I_{1}\left(a u^{3}\right) \exp \left[-\frac{3}{2} \xi\left(u-\frac{u^{3}}{3}\right)\right]\right\},
\end{aligned}
$$

where

$$
a=\frac{\xi \eta}{1+\eta^{2}}, \quad \xi=\frac{4 \pi R}{3 \lambda \Gamma^{3} \sqrt{1+\eta^{2}}} .
$$

The integration path is taken along the line of steepest descent from a saddle point [13], $I_{0,1}(z)$ is the modified Bessel function. A key parameter of the radiation analysis is

$$
\eta=\frac{v_{\perp}}{v_{d r}} \approx \frac{e B R \theta_{p}}{m_{e} c^{2} \Gamma}
$$

where the pitch angle $\theta_{\mathrm{p}}$ is defined as:

$$
\theta_{p}=v_{\perp} / v_{\|} .
$$


Correct estimation of the ratio $\theta_{p}=v_{\perp} / v_{\|}$during the experiment is an important part of spectra analysis. Uncertainties during measurement of the ratio $v_{\perp} / v_{\|}$may cause large errors during spectra analysis.

The single-electron spectral density of the synchrotron radiation $P(\lambda, \alpha)$ depends on cyclotron gyration phase $\alpha$ $\left(\dot{\alpha} \approx-\omega_{B}\right)$ and oscillates strongly with $\alpha$. In tokamaks the radiation of many runaway electrons is observed in the detector simultaneously. In this case, it is possible to introduce an averaged spectral density of the emitted power:

$$
P(\lambda)=\frac{1}{2 \pi} \int_{0}^{2 \pi} d \alpha P(\lambda, \alpha)
$$

There is a difference between Eq. (2) and Schwinger's result [14]:

$$
P_{S c h}(\lambda)=\frac{4 \pi c e^{2}}{\sqrt{3} \lambda^{3} \Gamma^{3}} \int_{w}^{\infty} K_{5 / 3}(x) d x,
$$

where

$$
w=4 \pi R_{\text {curv }} / 3 \lambda \Gamma^{3} .
$$

Here $R_{\text {curv }}$ is the instantaneous curvature radius. Equation (7) describes the emission of a single electron, meanwhile Eq. (2) describes the radiation of many runaway electrons whose distribution function is independent on the phase of cyclotron gyration $\alpha$ i.e., distribution function has the form $f\left(p_{\|}, p_{\perp}, t\right)$.

The asymptotic approximation of integral (2) simplifies the spectra analysis. Integral (2) can be easily integrated by saddle point method (see, e.g. [13]) when $\xi>>1$,

$$
\xi=(4 \pi / 3)\left(R / \lambda \Gamma^{3}\right)\left(1 /\left(1+\eta^{2}\right)^{1 / 2}\right)>>1
$$

Two limit cases are possible (see [5]). In the first case (the saddle point is $u_{0}=(1,0)$ )

$$
P_{a s 1}(\lambda) \approx \pi c e^{2} \sqrt{\frac{2 \sqrt{1+\eta^{2}}}{\lambda^{5} R \Gamma}}\left[I_{0}(a)+\frac{4 \eta}{1+\eta^{2}} I_{1}(a)\right] \exp \left(-\frac{4 \pi}{3} \frac{R}{\lambda \Gamma^{3}} \frac{1}{\sqrt{1+\eta^{2}}}\right)
$$

when

$$
a=(4 \pi / 3)\left(R / \lambda \Gamma^{3}\right)\left(\eta /\left(1+\eta^{2}\right)^{3 / 2}\right) \lesssim 1 .
$$

The asymptotic expression (10) for $P_{\text {asl }}(\lambda)$ is valid for $\eta>>2$ or $\eta<<0.5$ as it follows from the inequalities (9) and (11).

In the second case (the saddle point is $\left.u_{0}=\left(\sqrt{1+\eta^{2}} /(1+\eta), 0\right)\right)$

$$
P_{a s 2}(\lambda) \approx \frac{\sqrt{3}}{2} \frac{c e^{2} \Gamma(1+\eta)^{2}}{\lambda^{2} R \sqrt{\eta}} \exp \left(-\frac{4 \pi}{3} \frac{R}{\lambda \Gamma^{3}} \frac{1}{1+\eta}\right)
$$

when

$$
a u_{0}^{3}=(4 \pi / 3)\left(R / \lambda \Gamma^{3}\right)\left(\eta /(1+\eta)^{3}\right)>1 .
$$

Expressions (10) and (12) have a maximum values at $\lambda_{m}$ [5]. The asymptotic expressions Eq. (10) and Eq. (12) describe correctly the features of the spectrum in the range $\lambda<\lambda_{m}$ only, where the value of $\xi$ is large, $\xi>>1$.

When $\eta$ is the order of several units $(\eta \sim(1-2))$, equation (12) has to be used. The analysis of experimental conditions (runaway shot \#28957) shows that it is just a case of the EAST tokamak. Note that an application of Eq. (10) is discussed only in the review paper [2].

In Eqs. (2-4) and Eqs. (9-13) the value of major radius $R$ corresponds to the runaway electron positions. Note that for simplicity of analysis in Ref. [5] and Ref. [11] the value of $R_{0}$ was used in the same expressions. The spectrum is shifted toward shorter wavelengths with increasing of parameter $\eta$. Recall that the experimental measurement of the spectrum in the region $\lambda<\lambda_{m}$, where $P(\lambda)$ decreases exponentially fast, is very important because it allows estimating the maximum energy of runaways in the discharge.

The integral (2) can be taken numerically without additional simplifications. It has been taken numerically along the contour $C$ (a hyperbola $x^{2}-y^{2} / 3=1$ passing through the saddle point $(x=1, y=0)$, where $x$ and $y$ are real and imaginary 
parts of the complex number respectively) in the complex plane to calculate accurately the spectrum near the maximum position. This integration path provides the most rapid convergence of the integral.

\section{RUNAWAY INVESTIGATION IN EAST}

The EAST tokamak is a non-circular advanced steady state experimental device. The EAST first plasma discharge was successfully achieved in 2006. The scientific mission of the EAST project is to study the physical issues involved in steady state advanced tokamak devices. The engineering mission of the EAST project is to establish the technology basis of fully superconducting tokamaks in support of future reactors.

The investigated runaway discharge was an ohmic discharge \#28957 [10,11] and was performed in the limiter configuration, with toroidal magnetic field $B_{0}=2 \mathrm{~T}$, plasma current $I_{\mathrm{p}}=250 \mathrm{kA}$, central line-averaged density $<n_{\mathrm{e}}>=2.2 \times 10^{19} \mathrm{~m}^{-3}$, plasma major radius $R_{0}=1.86 \mathrm{~m}$ and minor radius $a=0.45 \mathrm{~m}$. At the plasma center, electron temperature $T_{\mathrm{e}} \approx 0.55 \mathrm{keV}$ was obtained from a soft x-ray pulse height analysis (PHA) system during the plasma current flat-top phase. Runaway electrons were created during the start-up phase of the discharge by the ohmic coil. Runaway electrons were located around the $q=2$ rational magnetic surface (ring-like runaway electron beam), where $q$ is the safety factor. A visible CMOS camera of the EAST tokamak operates in the narrow $(0.38-0.75) \mu m$ wavelength range. The camera was located in the equatorial plane looking tangentially into the direction of runaway electron approach.

In Ref. [11] on the base of synchrotron radiation spectra and synchrotron radiation spot shape joint analysis the values of runaway electron parameters were obtained. It was deduced that the energy $E$ of runaways was $E=30 \mathrm{MeV}$ and pitch angle $\theta_{p}$ was $\theta_{p}=0.16$ (Fig.9-11 in Ref. [11]). But in Ref. [11] for this runaway shot \#28957 the analysis of runaway electron parameters was carried out on the basis of the asymptote Eq. (12) only.

\section{ANALYSIS OF SYNCHROTRON RADIATION SPECTRA FOR THE EAST SHOT \#28957}

The presented calculation of the synchrotron radiation spectra was based on precise expression for spectral density Eq. (2) for parameters of runaway electrons obtained in the recent EAST experiment (shot \#28957, [11]). The numerical integration of $P_{\text {full }}$ was carried out by the method of the steepest descent [13]. For these parameters, the comparison of radiation spectra obtained from precise expression Eq. (2) with data of asymptotic expressions Eq. (12) was carried out. Results of comparison for energy $E=(26,30) \mathrm{MeV}$ and for pitch angles $\theta_{p}=0.16,0.18$ are shown in Fig. 1. The wavelength operation range detected by the EAST visible light camera $(0.38-0.75 \mu \mathrm{m})$ is shown in these figures also. The spectrum moves to the smaller values of wavelength not only with energy increasing but also with pitch angles increasing [5]. In the case of runaway energy $E=30 \mathrm{MeV}$, the intensity of synchrotron radiation is much higher in comparison with energy $E=26 \mathrm{MeV}$.

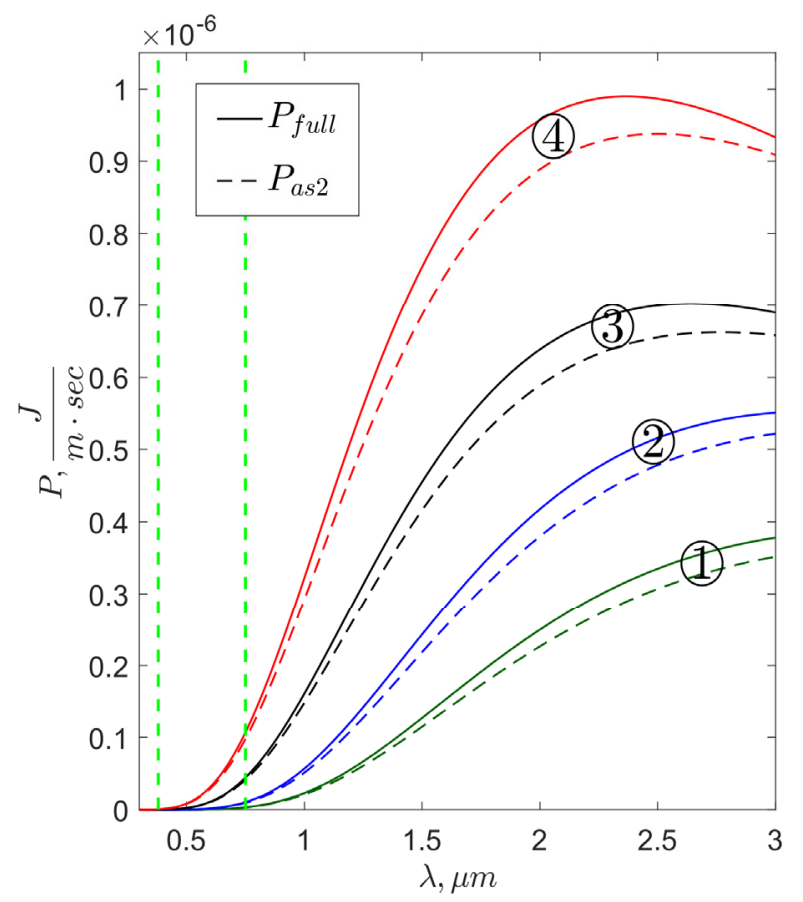

Fig. 1. Synchrotron radiation spectra analysis for runaway electron parameters in the EAST experiment: (1) $E=26 \mathrm{MeV}, \theta_{p}=0.16$, (2) $E=26 \mathrm{MeV}, \theta_{p}=0.18$, (3) $E=30 \mathrm{MeV}, \theta_{p}=0.16$, (4) $E=30 \mathrm{MeV}, \theta_{p}=0.18$. The wavelength operation range for the visible light camera $(0.38-0.75) \mu m$ is marked with vertical dashed lines.

For wavelength region $\lambda<<\lambda_{m}\left(\lambda_{m}\right.$ is the wavelength at which spectrum of runaway electrons has a maximum) the 
precise $\left(P_{\text {full }}\right)$ and asymptotic $\left(P_{a s 2}\right)$ curves practically are coincided for all cases. Hence, the validity of using asymptotic expression Eq. (12) in Ref. [11] for analyzing of synchrotron radiation spectra during recent runaway EAST experiment near the wavelength operation range $(0.38-0.75) \mu \mathrm{m}$ of the CMOS visible light camera has been confirmed, it is the main conclusion from data presented in Fig. 1. When the energy of runaway electrons is $E=30 \mathrm{MeV}$ this difference between $P_{\text {full }}$ and $P_{a s 2}$ is a little bigger but still negligible. As it was declared in Ref. [11], the synchrotron radiation is barely visible for runaway electrons with $E=26 \mathrm{MeV}$.

However, we notice that with increasing of wavelength the difference between asymptote and precise expression increases. A comparison of precise expression for synchrotron radiation spectrum of runaway electrons Eq. (2) with asymptotic expression Eq. (12) for wide wavelength range shows that the difference between $P_{\text {full }}$ and $P_{\text {as } 2}$ becomes more significant when the wavelength is approaching to $\lambda_{m}$. Hence, for wavelengths in the range of $\lambda \sim \lambda_{m}$ precise expression Eq. (2) should be used instead of asymptote Eq. (12) for investigation of runaway electron parameters.

\section{CONCLUSIONS}

For recent the runaway EAST experiment parameters (Ref. [11]) detail analysis of synchrotron radiation spectra of runaway electrons using precise expression for spectral density Eq. (2) has been presented. For wavelengths $\lambda<<\lambda_{m}$ the validity of using asymptotic expression Eq. (12) for analyzing of synchrotron radiation spectra parameters in wavelength operation range of the EAST visible light camera $(0.38-0.75 \mu \mathrm{m})$ has been confirmed, $\lambda_{m}$ is the wavelength at which spectrum of runaway electrons has a maximum. It is emphasized that if for analysis to use the wavelength range near maximum value of spectra, where $\lambda$ is close to $\lambda_{m}$, the precise expression of spectral power density $P_{\text {full }}$ should be used.

Obtained results are important for correct interpretation of runaway EAST experiments and runaway experiments in other tokamaks.

\section{REFERENCES}

1. Progress in the ITER physics basis. Chapter 3: MHD stability, operational limits and disruptions // Nuclear Fusion. - 2007. Vol. 47. - No. 6. - P. 128-202.

2. Jaspers R., Lopes Cardozo N.J., Donne A.J.H., et al. A synchrotron radiation diagnostic to observe relativistic runaway electrons in tokamak plasma // Review Sci. Instruments.- 2001.- Vol. 72-II. - No.1.- P. 466-470.

3. Finken K.H., Watkins J.G., Rusbuldt D., et al. Observation of infrared synchrotron radiation from tokamak runaway electrons in TEXTOR // Nuclear Fusion.- 1990.- Vol. 30. - No.5.- P. 859-870.

4. ITER physics basis, chapter 7: measurement of plasma parameters // Nuclear Fusion.- 1999.- Vol.39. - No. 12.- P. 2541-2575.

5. Pankratov I.M. Analysis of the synchrotron radiation spectra of runaway electrons // Plasma Physics Reports.- 1999.- Vol. 25. - No. 2.- P. 145-148.

6. Reux C., Plyusnin V., Alper B., et al. Runaway electron beam generation and mitigation during disruptions at JET-ILW // Nuclear Fusion. - 2015. - Vol. 55. -No. 9. - 093013.

7. Yoshino R., Tokudo S., Kawano Y. Generation and termination of runaway electrons at major disruptions in JT-60U // Nuclear Fusion. - 1999. - Vol. 39. - No. 2. - P. 151-161.

8. Yu J.H., Hollmann E.M., Commaux N., et al. Visible imaging and spectroscopy of disruption runaway electrons in DIII-D // Physics of Plasmas. - 2013. - Vol. 20. - No. 4. - 042113.

9. England A.C., Chen Z.Y., Seo D.C., et al. Runaway electron suppression by ECRH and RMP in KSTAR // Plasma Science and Technology. - 2013. - Vol. 15. - No. 2. - P. 119-122.

10. Zhou R.J., Hu L.Q., Li E.Z. et al. Investigation of ring-like runaway electron beams in the EAST tokamak // Plasma Phys. Control. Fusion.- 2013.- Vol.55. - No. 5.- 055006.

11. Zhou R.J., Pankratov I.M., Hu L.Q., et al. Synchrotron radiation spectra and synchrotron radiation spot shape of runaway electrons in Experimental Advanced Superconducting Tokamak // Physics of Plasmas. - 2014. - Vol. 21. - No. 6. - 063302.

12. Pankratov I.M., Pavlenko I.V., Pomazan O.A. Analysis of synchrotron radiation emitted by runaway electrons in tokamaks // The Journal of Kharkiv National University, physical series "Nuclei, Particles, Fields". - 2013. - No.1059. - Iss. 39. - P. 39-45.

13. Olver F.W. Asymptotics and Special Functions.- Natick: A K Peters, 1997.- 592 p.

14. Schwinger J. On the classical radiation on accelerated electrons // Phys. Review.- 1949.- Vol. 75. - No. 12.- P. $1912-1925$. 